\title{
CONCEPTUALISATION OF CONSCIOUS LEADERSHIP
}

\author{
Dejan Marinčič* \\ Faculty of Organizational Sciences in Kranj, University of Maribor, Slovenia \\ Miha Marič \\ Faculty of Organizational Sciences in Kranj, University of Maribor, Slovenia
}

\begin{abstract}
Conscious leadership is a recent construct, which we do not yet know much about. Most leaders already have their own way of management, which they often associate with their way of life. Thus, we know various ways of managing. A true conscious leader must be aware of his position and his mission, and must strive to be educated every day, work on his own consciousness, form his own context of life, try to perceive information from the surroundings, learn from life experiences, and closely monitor all the events around him. There are many ways to teach us how to become a good leader, and we ourselves need to figure out which theory and method of leadership best suits us and is most appropriate for us. In conscious leadership, we must first become self-aware. We must have a systemic insight, must be conscious of things and build on collective consciousness. Conscious guidance is a way of life that we build for years and years. A good conscious leader is the one who learns and improves daily until the end of his career and wants to leave a positive mark on the world. We will study what influences the level of conscious leadership, how it happens and how we can become a good conscious leader. We will achieve this through a critical review of secondary literature and a synthesis of relevant literature addressing this topic as well as literature dealing with a clarified narrow scientific field of conscious leadership and the effects of conscious leadership on followers in organisations. We will also create a conceptual model of conscious leadership.
\end{abstract}

Key words: conscious leadership, organization, management, awareness, conceptualization, conscious management

JEL classification: M12

*dejkom@gmail.com 


\section{KONCEPTUALIZACIJA SVESNOG LIDERSTVA}

Sažetak: Ideja svesnog liderstva se nedavno pojavila, te se o njoj još ne zna mnogo. Većina lidera već ima način upravljanja koji je često povezan sa njihovim načinom života, a upoznati smo sa brojnim načinima upravljanja. Pravi svesni lider mora biti svestan svoje pozicije $i$ misije, mora se usavršavati svaki dan, raditi na sopstvenoj svesti, kreirati svoj životni kontekst i svesno opažati informacije iz svoje okoline, učiti iz životnog iskustva i sagledavati sve događaje koji se dešavaju oko njega. Postoje mnogi načini na koje se može naučiti kako se postaje lider, a mi sami moramo odlučiti koja nam teorija $i$ metod liderstva najviše odgovaraju i koji su najprikladniji. U svesnom liderstvu najpre moramo postati svesni sebe. Moramo imati sistemski uvid u sopstvenu svest, ali da budemo svesni i stvari oko sebe, te da nadograđujemo kolektivnu svest. Svesno vođenje je način života koji se gradi godinama. Dobar svesni lider je onaj koji svakodnevno uči i usavršava se do kraja života, onaj koji želi da ostavi pozitivan trag $u$ svetu. U ovom radu ćemo proučavati šta je to što utiče na nivo svesnog liderstva i kako se može postati dobar svestan lider. Ovo ćemo postići kritičkim pregledom sekundarne literature i sintezom relevantne literature koja se bavi temom liderstva, kao i sintezom one literature koja se bavi uskim naučnim poljem svesnog liderstva i efektima svesnog liderstva na sledbenike u organizacijama. Takođe ćemo izložiti i konceptualni model svesnog liderstva.

Ključne reči: svesno liderstvo, organizacija, upravljanje, svesnost, konceptualizacija, svesno upravljanja, menadžment

\section{INTRODUCTION}

Many of us know the quote of John Mackey, CEO of the Whole Foods Market, who said that the organisation could only be as conscious as its leader. This quote opens a new mind-set and a new view towards the leadership. When we begin to recognise conscious leaders, we are enchanted with their thinking and problem solving. Business is an integral part of everyday life worldwide. Organisations around the world are currently structured in such a way that their main purpose is earning. However, conscious leadership strives not only for earnings, but also for the general good and for leaving a wide positive mark. Organisations can thus become a major force in improving welfare around the world. Conscious leadership is a new potential that is suitable for smart and successful leadership of organisations in the new world. It is a world that is strongly connected and increasingly mindful, requires greater transparency, has greater relevance, a greater purpose, a greater integration of values, strives for integrity, has greater responsibility and responsibility for the effects that we create in the world (Hayden, 2016). 


\section{WHAT IS CONSCIOUS LEADERSHIP?}

A leader of a group of people or a head of an organisation must find an effective way of managing in order to be successful. Conscious leadership means to maintain awareness of thoughts, feelings and experiences to achieve a goal. A conscious leader must also be conscious of his mindfulness in everyday life and must work on it. A conscious leader must have the following characteristics: he must see a problem from different perspectives, but at the same time he must remain neutral; collect information and learn from experience; be clear in discussions; he must be able to assume responsibility; he must communicate fairly and openly; he must aim towards a positive outcome (Ward \& Haase, 2016).

Jones and Brazdau (2015) describes mindfulness as a theory of socio-cultural knowledge of reciprocity, which enables the leader to detect patterns in the environment and connections among several problems that he is trying to solve for the common good. Klopčič (2009) defines conscious leadership as a complete responsibility for the acceptance of activities and communication. We must form communication in a way that achieves the desired effects.

A leader cannot work in that way without leading. Sometimes, a leader leads in a direction he does not want to take. And, when he finds himself somewhere where he does not want to be, he does not know he reached that direction. At that moment, he must ask a conscious question: "Is this the effect that we want to achieve?" If the answer is no, then he must ask himself, how he should form the established situation; what to say, how to communicate, what words to use, what kind of phrases to create? It is important to create such communication that allows creation of opportunities. This provides great opportunities for further learning. We must be aware that leadership is formed in a relationship. The key issues that we need to address are how to connect with colleagues and how to develop a good relationship (Ward \& Haase, 2016).

\subsection{MINDFULNESS OF THE LEADERS}

Leadership is linked to effective 'capturing' and directing of collective attention. Attention requires to first focus on our own attention, then to attract, direct and maintain the attention of others, employees, business partners, and customers (Ellis, 2015). The leader's attention field, reflected in the specific issues and objectives on which he focuses, draws the attention of those who follow him. Inspiring guiding requires harmonisation with both the inner emotional reality and the emotional reality of the people we want to inspire. Not achieving the goal is not a failure, but not connecting with people is. The mode 
of operation, which only focuses on the fact that the work is done, is trampling the issues of humanity (Goleman, 2016).

Time begins to run faster when mindfulness rises, for example, when we enjoy working. At that time, mindfulness is at a very high level. Impatience and excessive expectations create constant pressure and stress that slow down the process. Low mindfulness is therefore useless, if not even harmful. We can only be reconciled with the flow of life with a high level of mindfulness (Cooper \& Croswell, 2011). A wide-open mindfulness forms a mental stepping-stone for creative breakthroughs and innumerable insights. There is no devil's advocate, no cynicism or judgment, in a wide-open mindfulness - only complete openness, susceptibility to everything that sinks into the mind (Goleman, 2016).

Leaders use different approaches to raise mindfulness. They connect with artists, read spiritual literature and search for spiritual teachers. Meditation practices have already been widely accepted. Development of mindfulness is also reflected in the shift in the scale of motives that are associated with higher needs, such as research, socialness and cooperation, inner strength, superior mastery, care for future generations, and serving higher goals (Zohar \& Marshall, 2006).

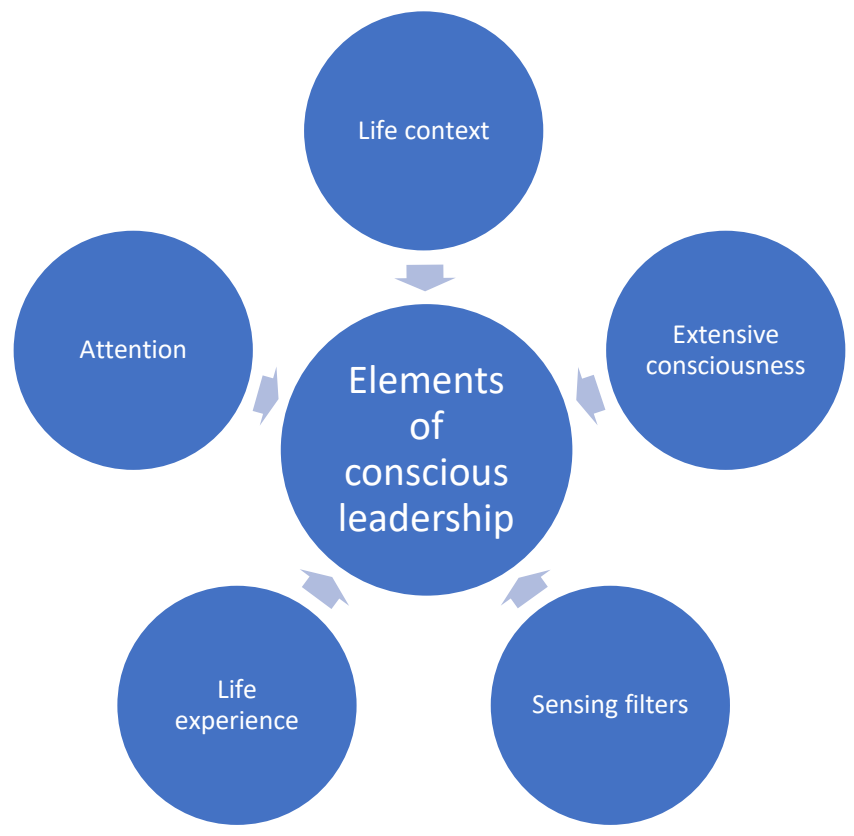

Figure 1. Elements of conscious leadership

Note. Authors. 
A conscious leader is responsible to act as a role model for his employees. $\mathrm{He}$ must respect every individual, and the employees must feel equal. This way, the employees strengthen their mindfulness. There are some basic elements of conscious leadership: attention, life context, extensive mindfulness, life experience, perceptual or sensing filters. These elements, shown in Figure 1, are a framework for understanding conscious leadership (Ward \& Haase, 2016).

A conscious leader can incorporate techniques of attentiveness and widespread mindfulness into his current management strategy. These techniques encourage him to become intentional and not audacious and reactive. This new way of responding to life is being confirmed and has the potential to help anyone become a conscious leader by including life context and extensive mindfulness (Kendall, 2018). Life context refers to a set of circumstances or facts that relate to a particular event or situation. Every person has his own life context. When a child is born, his family creates guidelines for his life. A child must decide how to live as a part of this family. When he grows up, he must have an opportunity to accept or reject the imposed cultural norms, rituals and beliefs. Everyone should be able to create his own life context, but a family plays a very important role in shaping this context (Ward \& Haase, 2016).

A conscious leader focuses on learning and goals and supports the spread of mindfulness to people around him. Various speakers teach about what mindfulness is. There are metaphysical and psychological aspects, which relate to religious beliefs and the search for the meaning of life. Psychologists Ron and Mary Hulnick (2010) define spirituality as a study and practice of art and science of human development in mindfulness. Psychology and spirituality are connected because they support mental and emotional health of the individual. A leader with the expanded mindfulness understands that every person has his own complex life experience. Each new day gives us new life experiences. A conscious leader seeks employees who are productive and positive (Cordova, 2018). However, he also associates with employees who are unhappy and unproductive. A conscious leader is trying to explore the source of the problem and eliminate it. Everyone has patterns and habits that have evolved from personal feelings and beliefs. These life experiences form either positive or negative beliefs (Hulnick \& Hulnick, 2010).

A conscious leader must recognise the feelings of both sides and resolve the disparity. Good detectable filters are helpful. If a negative situation occurs in an organisation, a leader with an extended mindfulness must study both sides and remain neutral. A leader can absorb the feelings of his employees in order to solve problems, while helping his employees to move towards the extended mindfulness (Ward \& Haase, 2016). 


\subsection{DEVELOPMENT OF EXTENDED MINDFULNESS}

Skills such as meditation, proper breathing, and listening with a heart (centring on the speaker's words) result in an increased mindfulness. Every day, by learning and observing the environment, we can improve our mindfulness. We need to explore what are the values of life; we must recognise what our life goal is (Renesch, 2010). Meditation is a powerful tool that strengthens the spirit and opens the way to extended mindfulness. With such a mind, one can better express his creative ideas and solutions. All ideas that come through the mind need to be analysed without judgment. It may be necessary to experiment at the beginning, so that everyone finds his own meditation technique that best suits them. Health and physical vitality, as well as mental and emotional peace, influence extended mindfulness. In the sixth century $\mathrm{BC}$, the Chinese philosopher Laozi spoke of the importance of observing oneself. The theory was based on the fact that an observer observes himself in peace, controls his thoughts and emotions. Figure 2 shows the elements of expanded consciousness (Ward \& Haase, 2016).

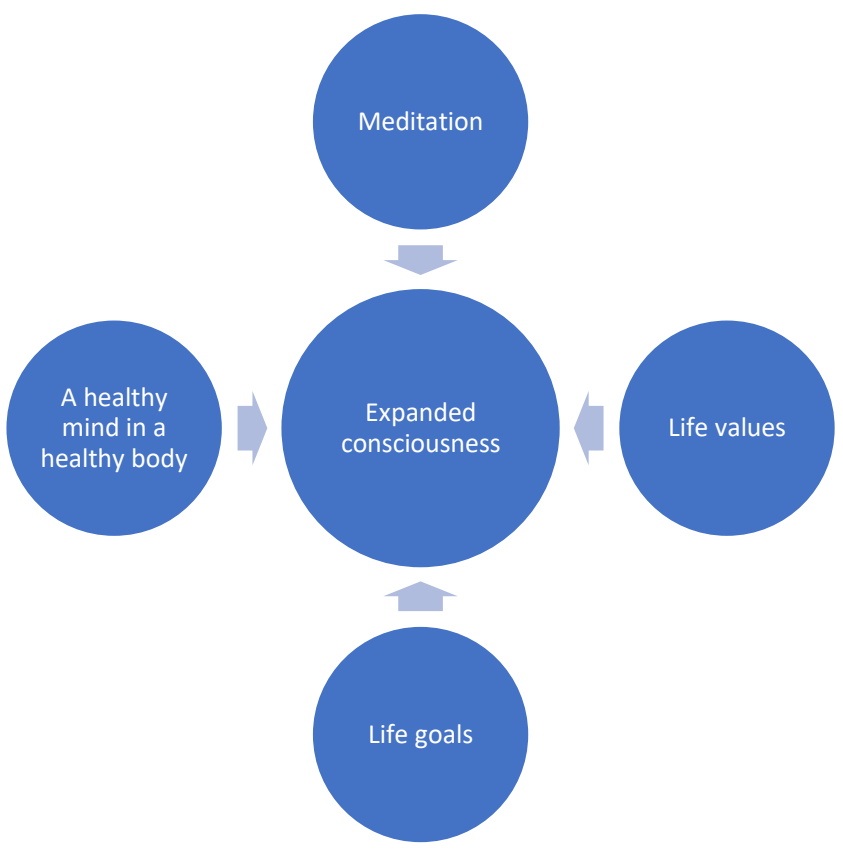

Figure 2. Elements of expanded consciousness.

Note. Retrieved from "Coaching Questions for Conscious Leaders" from Hayden, G. (2017). Conscoius Leadership Consultancy. 


\subsection{MODEL OF CONSCIOUS LEADERSHIP}

Hayden (2017) identifies four key elements in the model of conscious leadership. First, a conscious leader must be self-aware and self-sufficient. He must live a conscious life of his choice; he must be aware of his values and values of others and include them in communication. He must have the ability to see more perspectives and not to identify with them. Another important element of the model is that the leader must be aware of things that lead relationships (Crosswell, 2010). This does not only involve being physically present, but a leader must also listen generously, discuss boldly and defend their positions, control, be responsible towards other people, and create opportunities for cooperation. Systemic insight is the third element of the model of conscious leadership. This means that a leader must have a highly developed mindfulness towards all participants, leading to strong systemic intelligence and the tendency to think and create benefits and balance in a wider system, and he must take responsibility for the long-term effect of his actions (Cohen, 2018). Collective awareness is the fourth element in this model and it is defined as an internal call and a sense of responsibility, which results in the wider common good and always has a positive effect (Hayden, 2017).

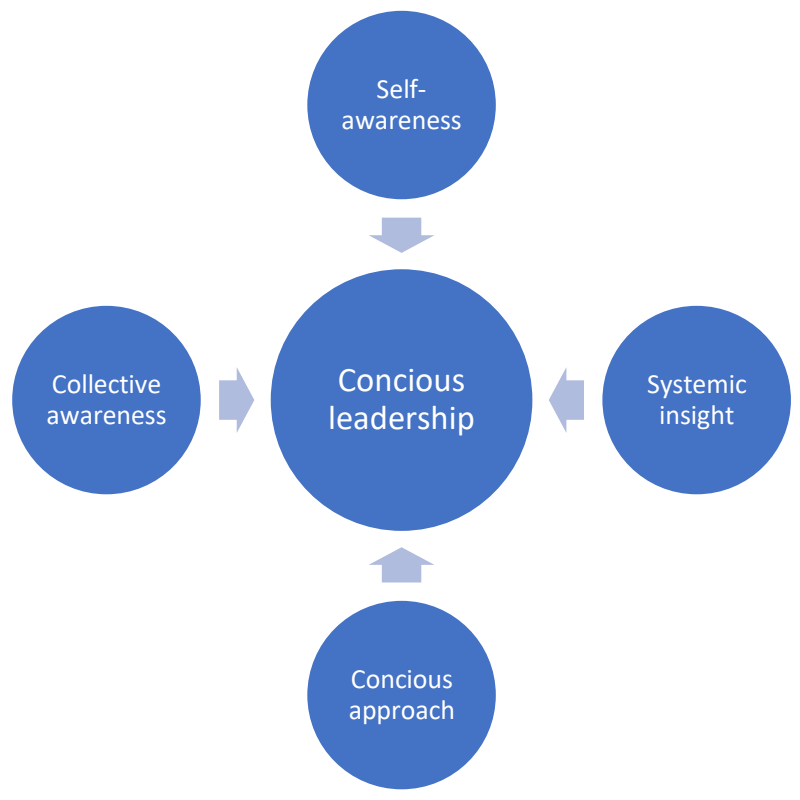

Figure 3. Elements of conscious leadership

Note. Authors. 


\subsection{CONCEPTUALIZATION OF CONSCIOUS LEADERSHIP}

Conceptualisation of conscious leadership is composed of three subgroups, which are mutually intertwined: expanded consciousness, elements of conscious guidance and conscious guidance. Expanded consciousness is co-created with the help of meditation, life values, life goals, and a healthy spirit in a healthy body. These elements can be taught and improved through daily exercise (Dethmer, Chapman \& Warner Klemp, 2015). They promote individual's internal growth and help shape one's true self and expression. The elements of conscious guidance are life context, expanded consciousness, sensory filters, life experiences, and attention. These elements can be more or less obvious in an individual, as each individual has different competences. As we know, some competences can be innate, some can be learned, and some are gained through life experiences. A proper conscious leader must be aware that every new day brings new experiences that he can take advantage of for his own good. The third element of conceptualisation of conscious leadership is conscious leadership. This subgroup of the concept is the most important for the entire process of conceptualisation, consisting of: self-awareness, systemic insight, collective consciousness, and leader's consciousness of things around him. These elements are crucial for the formation of a good conscious leader.

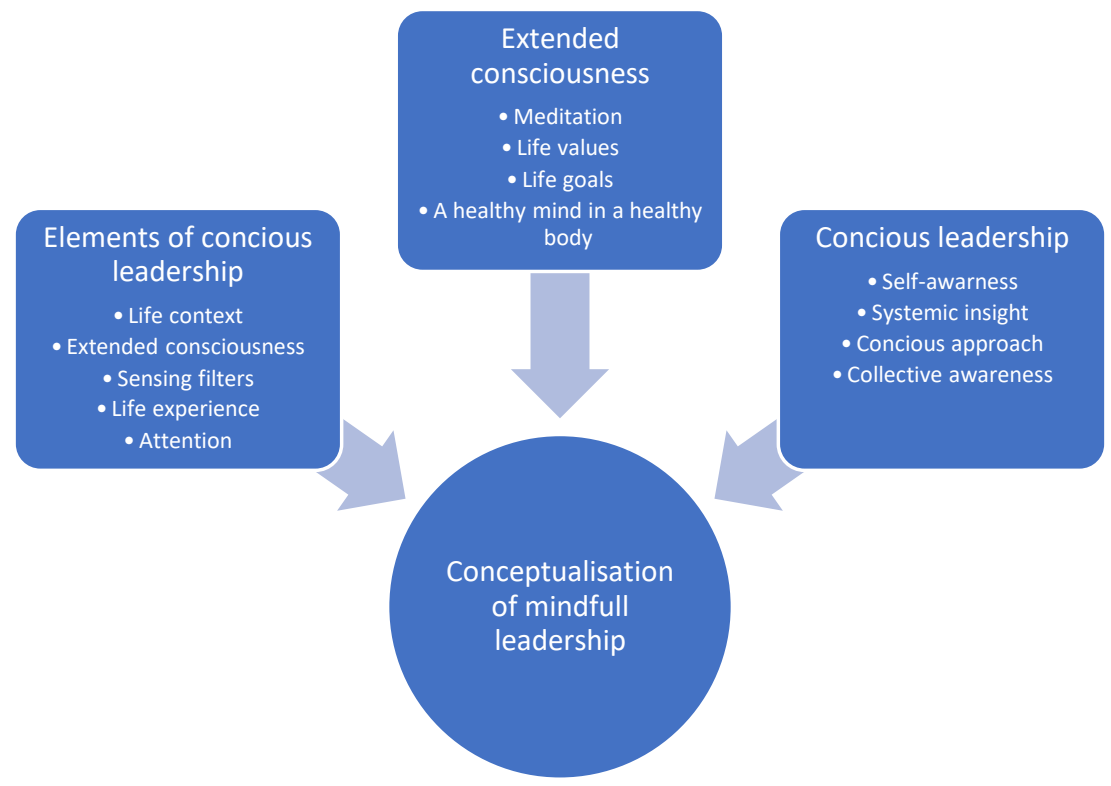

Figure 4. Overview of the conceptualization of conscious leadership

Note. Authors. 


\section{DISCUSSION AND IMPLICATIONS}

A new era leader upgrades his competences and adds new dimensions to them. Mindfulness, energy and love require additional dimensions for successful leadership in the new era. A new era leader is also aware of the responsibility for the material, emotional and spiritual well-being of the organisation. He acts with love for spontaneity and his deepest values. He continuously upgrades and develops all dimensions of perception, intelligence, including emotional and spiritual intelligence, and takes care of his physical vitality (Klopčič, 2016).

Leading in this new world requires us to encourage co-operation between different parties, each of which has a different insight into reality. The role of the leader is to help and associate different thinkers and integrate them into a whole, so that they can work smoothly. Conscious leaders see their world differently, as they can receive more information from the environment, they can listen to others, accept contradictions and paradoxes, promote co-operation, include different perspectives and combine systems, are flexible with their hierarchies, and decentralise control. Conscious leaders can use their intuition to overcome their rational thinking (VUCA World, 2017).

Business is a powerful force in the world. It is sensible to form as many conscious leaders as possible for the benefits that can be derived from transformed organisations, their employees, their stakeholders and their system. The highest quality of a conscious leader is his ability to see how his work has a potential to transform mankind.

There are conscious leaders such as Tom Chi, inventor, innovator and founder of Prototype Thinking LLC, who is already striving to lead his company consciously. Tom says that his goal is to add value to people in a thousand years, and that people should serve humanity. A conscious leader represents a new definition of success, defined by measures such as action with meaning and happy humanity. Such leaders have built the foundations of traditional success criteria by transforming companies fundamentally. This is an unselfish success, which is not defined by personal glory, but is an attempt to make a better tomorrow (Hayden, 2016).

\section{CONCLUSION}

The current top business leaders, such as John Mackey of Whole Food Markets, Eric Schmidt of Google and Anna Roddick of the Body Shop, have a common belief that they have changed the style of leadership to conscious leadership. They all made a transition to a new management style that considers the importance of financial results and how to achieve them. They found that sustainable success in today's market is defined by more than sort-term profit 
goals and maximizing the wealth of shareholders. This is a necessary but not a sufficient condition for sustainable success in the world, which is becoming increasingly more sensitive to negative effects of this profit. It is now a matter of good leaders to treat people, profit and the planet as the need for their management (Rydin, 2017).

The theory of conscious leadership is based on the sociocultural knowledge of reciprocity, which enables the leader to detect a pattern in the environment. Conscious leaders are aware of the organization and work with employees. A key to understanding this theory is the readiness to recognize and understand consciousness as the most critical part of the framework. Management therefore teaches and enables everyone in the organization to participate, and learn how to cooperate, which promotes personal and group responsibility to the wider common good (Jones \& Brazdau, 2015).

All these thoughts and conclusions that we have written are merely academic rhetoric, unless we endeavour to support them and start implementing them. We feel that it is time to dive in, to study ourselves and to raise our awareness, and to feel the consciousness that binds us to humanity and create a better tomorrow that will serve future generations.

\section{REFERENCES}

Cohen, J. (2018). 5 Ways To Be A Conscious Leader. Retrieved on 2. January 2019 from: https://www.forbes.com/sites/jennifercohen/2018/07/19/5ways-to-be-a-conscious-leader/

Ellis, C. (2015). The Secret Power of Conscious Leadership. Retrieved on 2. January 2019 from Liquidplanner: https://www.liquidplanner.com/blog/the-secret-power-of-consciousleadership/

Cordova, C. (2018). 10 Things You Need to Know to Be a Conscious Leader. Retrieved on 2. January 2019 from Chopra: https://chopra.com/articles/10-things-you-need-to-know-to-be-aconscious-leader

Cooper, D., \& Croswell, K. (2011). Ključi do vesolja. Založba Cangura.com.

Dethmer, J., Chapman, D., \& Warner Klemp, K. (2015). The 15 commitments of conscious leadership: A new paradigm for sustainable success. Conscious Leadership Group.

Goleman, D. (2016). Fokus, Skrito gonilo odločnosti. Novo mesto: Založba Penca. 
Hayden, G. (2016). A Deeper Look into the Conscious Leader. Retrieved on 2. January 2019 from Conscious Leadership Consultancy: http://consciousleadershipconsultancy.com/a-deeper-look-into-theconscious-leader/

Hayden, G. (2017). Coaching Questions for Conscious Leaders. Retrieved on 2. January 2019 from Conscoius Leadership Consultancy: http://consciousleadershipconsultancy.com/coaching-questions-forconscious-leaders/

Hulnick, H., \& Hulnick, M. (2010). Loyalty to Your Soul: The Heart of Spiritual Psychology. Carisbad, CA: Hay House, Inc.

Jones, V., \& Brazdau, O. (2015). Conscious Leadership, a Reciprocal Connected Practice. A Qualitative Study on Postsecondary Education. Procedia - Social and Behavioral Sciences, 203, 251 - 256.

Kendall, A. (2018). What is Conscious Leadership. Retrieved on 2. January 2019 from Applied Corporate Governance: https://www.appliedcorporate-governance.com/what-is-conscious-leadership/

Klopčič, S. (2009). Zavestno vodenje. Retrieved on 2. January 2019 from ileaders: http://www.i-leaders.net/2009/11/zavestno-vodenje.html

Klopčič, S. (2015). Voditeljstvo - Vodenje in sodelovanje, moč in odgovornost. Zagorje ob Savi: Sonja Klopčič s.p.

Klopčič, S. (2016). The Energy Inside Leadership. Zagorje ob Savi: Sonja Klopčič s.p.

Renesch, J. (2010). Conscious Leadership: Transformational Approaches to a Sustainable Future. The Journal of Values-Based Leadership, 3(1).

Rydin, S. (2017). Why Conscious Leadership Is The New Management Imperative. Retrieved on 2. January 2019 from Business Integral: https://www.businessintegral.com/why-conscious-leadership-is-the-newmanagement-imperative/

VUCA World. (2017). Leadership in the New World: The Rise of the PostHeroic, Conscious Leader. Retrieved on 2. January 2019 from Conscoius Leadership Consultancy: http://consciousleadershipconsultancy.com/leadership-in-the-new-worldthe-rise-of-the-post-heroic-conscious-leader/

Ward, S. F., \& Haase, B. (2016). Conscoius Leadership. AORN Journual, 104(5), 433.e1-433.e9. 
186 | CONCEPTUALISATION OF CONSCIOUS LEADERSHIP

Zohar, D., \& Marshall, I. (2006). Duhovni kapital - Bogastvo, od katerega lahko živimo. Ljubljana: Založba Tozd.

Delivered: 08.11.2018.

Accepted: 02.02.2019. 